Informatika i sistemy upravleniya. - 2017. - No. 2(52). - P. 109-118.

Eremin E.L. (ereminel@mail.ru)

Amur state university

\title{
ALGORITHMS OF ADAPTIVE SYSTEM FOR PLANT WITH SATURATION AND CONTROL DELAY
}

The article considers the way of constructing adaptive control system by uncertain single-channel object with control delay without measuring its state variables in the circuit with filter-corrector and modified standard predictor when under saturation or nonlinearity (non-affinity) of a control signal the plant is subject to influence of uncontrollable, but limited indignations. In order to eliminate saturation effect either totally or partially on control system functioning in regulator structure there should be applied a dynamic switch providing set scaling of amplification factors in a contour of a regulator selfadjustment.

Keywords: plant with control saturation and delay, modified standard predictor, filter-corrector, dynamic switch, aprioristic parametric uncertainty, structural indignation, adaptive regulator, hyperstability, $L$-dissipativity.

DOI: 10.22250/isu.2017.52.109-118

\section{For citation:}

Eremin E.L. ALGORITHMS OF ADAPTIVE SYSTEM FOR PLANT WITH SATURATION AND CONTROL DELAY // Informatika i sistemy upravleniya. - 2017. - No. 2(52). - P.109-118. 